\title{
Sustainable and Economic Alternative for the Electric Supply of Isolated Communities in the Brazilian Off-Grid Systems
}

\author{
Rebeca Doctors*, Rafael Kelman \\ PSR, Rio de Janeiro, Brazil \\ Email: *rebeca.de-bakker-doctors@poly technique.edu
}

How to cite this paper: Doctors, R. and Kelman, R. (2017) Sustainable and Economic Alternative for the Electric Supply of Isolated Communities in the Brazilian Off-Grid Systems. Journal of Power and Energy Engineering, 5, 145-155.

https://doi.org/10.4236/jpee.2017.59012

Received: September 1, 2017

Accepted: September 26, 2017

Published: September 29, 2017

Copyright (c) 2017 by authors and Scientific Research Publishing Inc. This work is licensed under the Creative Commons Attribution International License (CC BY 4.0). http://creativecommons.org/licenses/by/4.0/

\begin{abstract}
Roughly $99 \%$ of the demand for electricity in Brazil is supplied by a national interconnected grid. The remaining $1 \%$ is spread in several "isolated systems" of the Amazon region-mini-grids that rely on expensive diesel gensets due to high commodity and transportation costs. The isolated systems also have remote communities disconnected altogether from the mini-grids with inadequate health, education and leisure services. These communities are precariously supplied by small inefficient diesel gensets that run for a few hours per day. In this article, we propose a sustainable and economic alternative for the electric supply of the remote communities of isolated systems through a combination of photovoltaic solar generation and storage. The objective is to improve access to electricity with savings for the communities. The present paper outlines a public policy to meet this objective.
\end{abstract}

\section{Keywords}

Off-Grid, Hybrid Systems, Public Policy, Solar Photovoltaic, HOMER

\section{Introduction}

The Brazilian interconnected electricity system (SIN) provides $99 \%$ of the national demand. In the last few years the larger cities of the Northern Brazil, such as Manaus and Rio Branco, have been connected to the SIN. The remaining 1\% is scattered in several mini-grids in the so-called "isolated systems", mostly in the Northern region of Brazil. Due to the use of inefficient gensets and overly expensive diesel, the cost of supply per MWh served of the isolated systems is ten times higher than the SIN and the emissions of carbon dioxide $\left(\mathrm{tCO}_{2} / \mathrm{MWh}\right)$ are roughly nine times higher [1]. Tariffs paid by consumers of isolated systems 
would be prohibitive if they weren't heavily subsidized by SIN customers through a charge known as Fuel Consumption Account that exceeds US\$ 2 billion per year [2].

Isolated grids themselves can be separated in two groups: 1) a larger share supplied by diesel gensets connected to the local mini-grids; 2) a smaller share of remote villages in rural areas either poorly connected or completely disconnected from the mini-grid, with the access to electricity relying mostly on small-scale diesel gensets.

Remote communities are usually supplied for a few hours per day. Local municipalities sometimes help with the genset purchase, while the Federal government is present through the Luz para Todos (Light for All) program, which seeks to reach $100 \%$ coverage of national power supply (it has achieved $99.5 \%$ so far) [3]. This program was institutionalized in 2003, through Federal Decree $n$. 4873 [4] and costs over US\$ 7 billion, with $75 \%$ coming from the federal government [5].

The implementation of the Luz para Todos program is done through two main approaches: 1) expansion of grid connection; or 2) individual systems (named SIGFI-Individual Electricity Generation Systems with Intermittent Sources) [4]. The technical specifications of the latter have been put in place by the National Power Agency (ANEEL), after regulation n. 83 of 2004 [6]. The SIGFI criteria may have different dimensions, which are dependent on the monthly power generation.

This article analyses the viability to supply these smaller communities through a solar system or a hybrid system composed of diesel genset and solar photovoltaic generation. Porto Walter, a municipality in the state of Acre, was selected as case study. It is representative of many more municipalities in the Amazon region with similar settings. Information was gathered from three sources: 1) a field trip to the location; 2) the latest census; and 3) data shared by the local power supplier.

It is important to evaluate alternatives to increase the availability of electricity to promote more educational, health and leisure services [3]. Improved power supply also promotes higher social mobility among these communities, as stated by residents in Porto Walter when discussing the Luz para Todos program [7].

The paper targets an energy policy to improve social indexes to poorly assisted communities, such as those in the Northern region of Brazil. It also contributes to a more sustainable and economic alternative for the electric supply in off-grid systems, through the higher penetration of renewable sources of energy.

The remainder of the paper is organized as follows: Section 2 presents the study case, Section 3 presents the methodology used and the simulations that were modeled, Section 4 presents the main results and the last section concludes.

\section{Study Case}

As a study case we chose Porto Walter, a municipality in the state of Acre (northwest of Brazil), located on the banks of the Juruá river at the confluence 
with the Humaitá river (see Figure 1). This municipality has 11,509 inhabitants [8] and has a low population density-only 1.5 inhabitants per $\mathrm{km}^{2}$ [9]. It is part of the third lot auctioned in 2015 for the State of Acre.

The local economy is mainly based on extractivism, essentially of wood and latex. Other economic activities, such as cattle-raising and subsistence farming are also present in the rural areas of Porto Walter [10]. In addition to that, the only local production is brick factory. Most goods are imported from Cruzeiro do Sul, the second biggest city of Acre, three hours away by boat.

According to the last census [11], 64\% of Porto Walter's population live in rural areas, and most families have five or more children. Currently, around $80 \%$ of households in the urban area have basic home appliances, such as refrigerator, oven and television. In the rural area, appliances are still limited due to the weak availability of power. Indeed, the owner of a home appliances shop in Porto Walter reported that when a remote community is electrically connected to the local grid, refrigerators and other appliances sales increase.

Porto Walter has twenty small remote communities, located in difficult access areas, usually 30 minutes away from Porto Walter's center. The community size ranges from five to 20 households. (Figure 2)

Remote communities are either electrically connected to local grid or have a local generator, whose costs are divided by the households. Electrical connection is usually unreliable due to the crossing of dense forests. The falling of a tree branch on the line may interrupt supply for more than a week, due to the lack of technicians in the area. The genset solution case, on the other hand, is costlier and discourages households from using more electricity. They seldom have

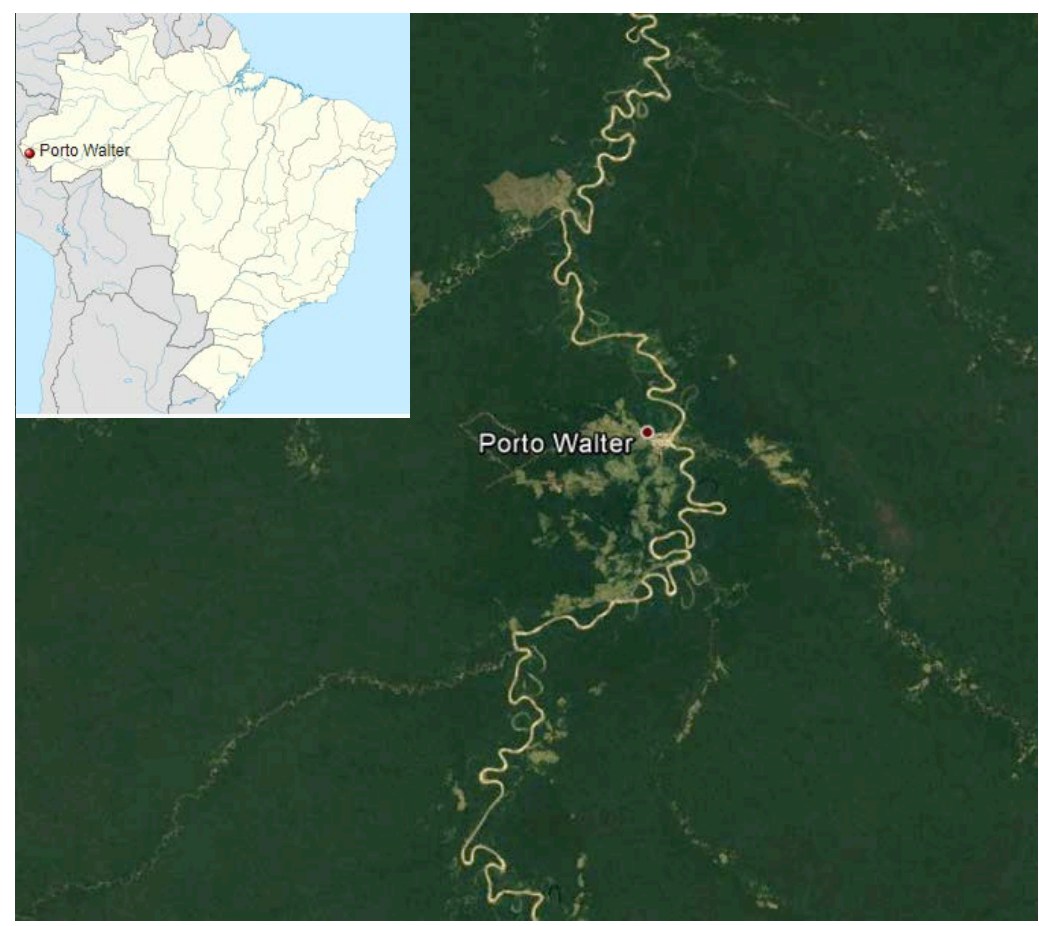

Figure 1. Example of a figure caption (figure caption). 


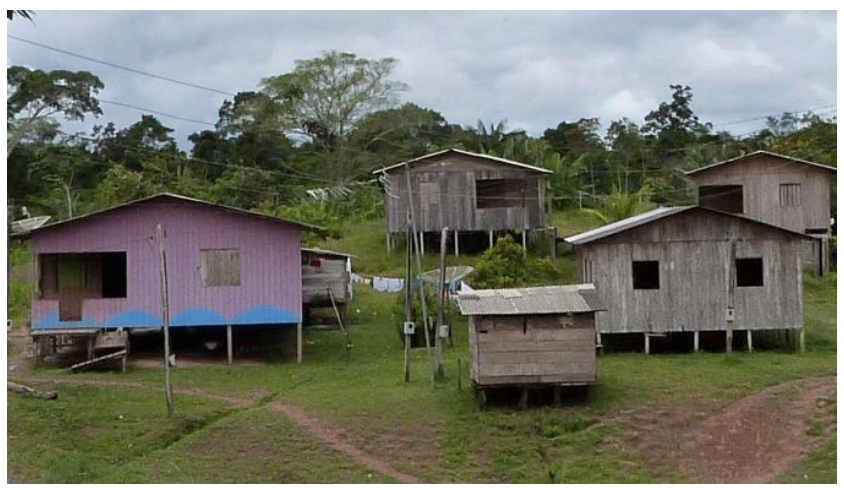

Figure 2. Houses in a rural area close to the center of Porto Walter.

refrigerators, for example, only lighting and basic appliances, such as radio and $\mathrm{TV}$, watched during the night.

The present paper investigates an alternative to the local diesel generator powering of remote communities. The next section describes the methodology that was used to assess more economic and sustainable solutions for remote communities.

\section{Methodology}

\subsection{Homer}

In order to evaluate alternatives to remote communities in the Brazilian off-grid system we used HOMER, a software for microgrids and hybrid systems simulations developed by NREL (National Renewable Energy Laboratory), a laboratory of the North American energy department [12]. HOMER is used for the planning of electrical systems both connected and disconnected from the grid.

To find the optimal solution - a combination of components to assemble the system to meet the market at the lowest cost-HOMER compares different alternatives in the following order: 1) first it simulates hourly operation of the system throughout a year for different configurations; 2) the configurations are compared in terms of present value of investment, operation and maintenance costs; the least-cost configuration is selected; 3) sensitivity analysis is allowed to measure the impact of the optimum solution for changes in selected variables [13], as to evaluate solution robustness (e.g., analyze whether the optimal configuration would be the same if the price of diesel changed).

The problem considers operative restrictions, such as reserve, load variability, battery charge/discharge logic and depth of discharge, degradation of photovoltaic modules and others. Meteorological conditions, such as solar global irradiance and temperature are also considered by the model when testing a configuration based on solar photovoltaics.

\subsection{System Sizing}

We estimate the household electricity consumption of a remote community from data gathered from local interviews during the field trip to Porto Walter. As al- 
ready mentioned, the supply is often made through a local generator that is bought by the residents themselves or purchased with the help of federal resources that were granted to the municipal administration. When there is a school or health center in one of these communities, the investment and fuel costs are shared with the municipal administration.

According to data provided by the secretary of Porto Walter, the local cost of a $10 \mathrm{kVA}$ generator with a $20 \mathrm{HP}$ motor is US\$13 thousand. A $10 \mathrm{kVA}$ generator serves a community of 10 households and the fuel used is diesel, which costs US\$ 1.60 per liter, with the daily consumption of a remote community being around 10 liters. The local diesel generator runs mostly at nighttime, usually from $18 \mathrm{~h}$ to $23 \mathrm{~h}$. Hence, households have little power availability.

Considering that an increase in the power availability would benefit these communities, we built a load curve based in the SIGFI60 criteria [14] of Luz para Todos, which considers a monthly energy consumption of $60 \mathrm{kWh}$ per household, which is applicable to an individual system with solar photovoltaic generation and storage.

To simulate the supply of a household in a remote community, we built a yearly load curve, to supply the following consumption: Five $13 \mathrm{~W}$ lamps $(6 \mathrm{~h} /$ day $)+$ one $50 \mathrm{~W}$ fan $(2 \mathrm{~h} /$ day $)+$ one $100 \mathrm{~W}$ TV $(4 \mathrm{~h} /$ day $)+$ one $300 \mathrm{~L}$ refrigerator (24 $\mathrm{h} /$ day), one cellphone charger ( $2 \mathrm{~h} /$ day) and a computer $(2 \mathrm{~h} /$ day $)$. The resulting load curve for January is shown in the figure bellow (Figure 3). We assume that the seasonal change of the load profile follows the observed load curve of the urban area of Porto Walter.

The system design was made observing SIGFI60 specifications [15]:

- Photovoltaic generator of $1 \mathrm{kWp}$;

- $1 \mathrm{~kW}$ inverter;

- Battery bank of $10 \mathrm{kWh}$ (two days of autonomy).

The simulations were made for a 25-year horizon, considering the lifetime of a solar photovoltaic system and batteries. We used the following local costs: US\$ 1.00/Wp for photovoltaic modules, US\$ 0.50/W for inverters and US\$ 170 per kWh of battery. The battery needs to be replaced after four years maximum. The lifetime, in turn, depends on the depth of discharge, as shown in the next figure (Figure 4) for the case of Lead Acid battery.

The meteorological data was based on the Renewables.ninja model [16], considering northern facing photovoltaic modules with a tilt similar to the local latitude [17]. The GHI (global horizontal irradiance) has a mean value of approximately $5.07 \mathrm{kWh} /$ day $/ \mathrm{m}^{2}$ for this location $(8.26 \mathrm{~W}, 72.75 \mathrm{~S})$. We consider the effect of temperature in the solar modules (average temperature is 25.6 Celsius), and the decrease of solar yield throughout module lifetime.

Two systems were simulated: 1) a hybrid system with a $10 \mathrm{kVA}$ diesel generator with a diesel cost of US\$ 1.60 per liter and US\$ 1300 investment cost per household (a tenth of the total cost, as it is shared by 10 households of a remote community); and 2) solar photovoltaic system with lead acid battery. 


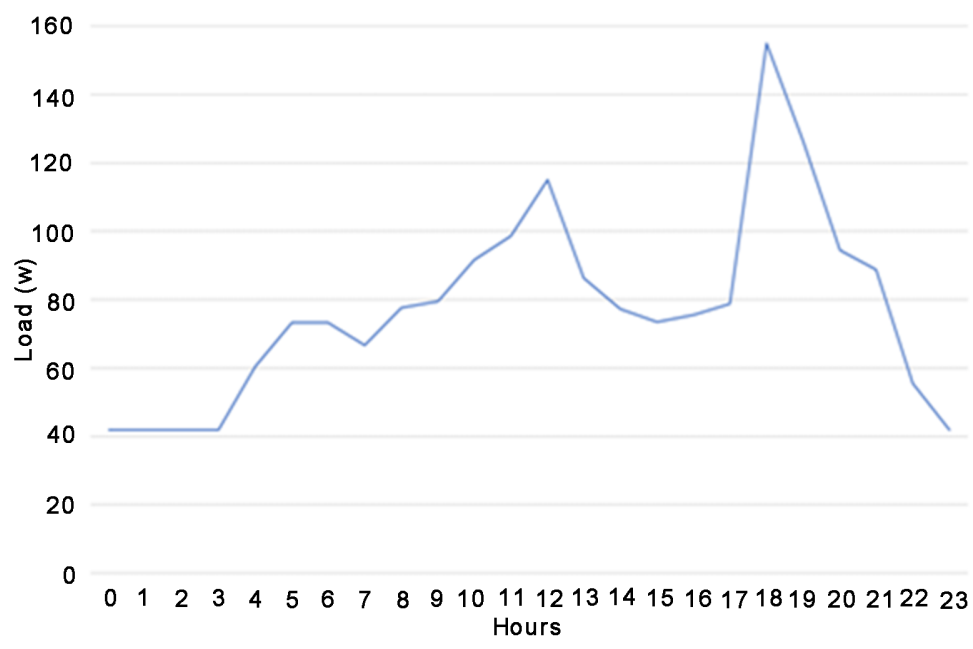

Figure 3. January load profile.

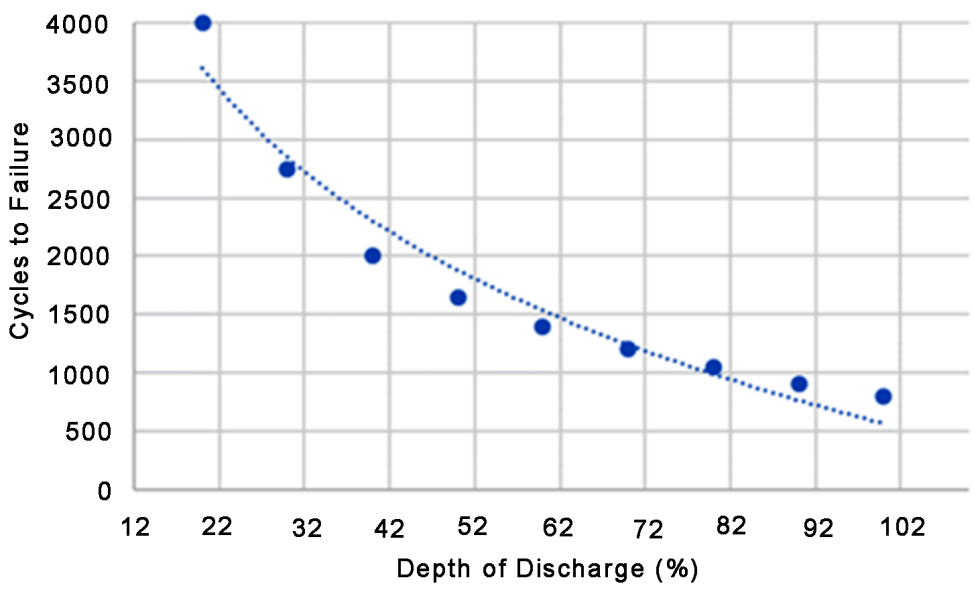

Figure 4. Lead acid battery lifetime curve.

Even though the current power supply is only done through local diesel gensets, it would still be more expensive than a hybrid system that combines solar photovoltaic generation. Hence, we decided to analyze a hybrid system versus an only photovoltaic system (with battery bank), since both alternatives would be less expensive than the only diesel one and they would also promote a higher share of renewable sources of energy in the isolated systems, a current concern to the high share of green house gases emissions.

Nonetheless, a financial comparison is done between the only diesel system and the least cost system that was optimized in our exercise (see section below). The latter was undertaken so that there is a clear comparison between the current and the alternative system.

Further to the dimensioning following the SIGFI60 criteria, we analyzed these two cases (hybrid and only solar photovoltaic system) with the HOMER software.

The HOMER optimizer module was used to dimension alternative systems to 
the one based after the SIGFI60 criteria. The following section explores the principal results of our simulations.

\section{Results}

The Two systems were simulated: a hybrid and photovoltaic only systems, considering design (sizing criteria of SIGFI60 and HOMER optimization). We compare the least expensive systems for a specific configuration. One of the principal results that were evaluated is the levelized cost of energy (LCOE), which is a commonly used metric to determine the competitiveness of a technology.

The photovoltaic-only system was found to be more competitive than the hybrid alternative. The LCOE of the photovoltaic system with batteries $(0.43 \mathrm{US} \$ / \mathrm{kWh})$ is significantly smaller than the one calculated for the hybrid system (1.60 US $\$ / \mathrm{kWh}$ ), considering the HOMER optimization (smallest LCOE). Hence, the photovoltaic-only solution with battery bank is preferable. We then compare this solution for the two different configurations, i.e., the one modeled after the SIGFI60 criteria and the one optimized by HOMER.

The design of the least cost configuration is different from the technical specifications of the photovoltaic system and batteries specified for the SIGFI60 within the Luz para Todos program. A likely explanation is that the relative cost of equipment has changed since SIGFI60 was defined in 2012. The table below (Table 1) shows that the configuration of SIGFI60 has a higher photovoltaic system installed capacity. In both cases, the same demand is met, although SIGFI60 specifications end up having more surplus (unutilized) electricity. SIGFI60 LCOE is much higher-mainly due to the larger battery requirements.

Below is a D-map of the hourly solar production during the first year for the photovoltaic system with the optimal design (Figure 5). The left vertical axis represents the hours in a day, the right vertical axis the solar photovoltaic production and the horizontal axis the days in a year. As seen, solar yield is higher from July to October, when the solar global irradiation is higher and temperature is lower.

The operation of the optimal photovoltaic system with lead acid battery for one week is shown in the Figure 6. As observed, the battery charges during daytime, reaching $100 \%$ in days with high photovoltaic yield. During nighttime, the battery discharges to supply electricity to the household.

Table 1. Comparison between SIGFI60 and optimum design for the only solar photovoltaic system.

\begin{tabular}{ccc}
\hline & SIGFI60 Configuration & Optimum Design \\
\hline Photovoltaic Panels $(\mathrm{Wp})$ & 1040 & 828 \\
Inverter $(\mathrm{W})$ & 1000 & 800 \\
Battery Bank $(\mathrm{kWh})$ & 10 & 4 \\
LCOE $(\$ / \mathrm{kWh})$ & 0.77 & 0.43 \\
\hline
\end{tabular}




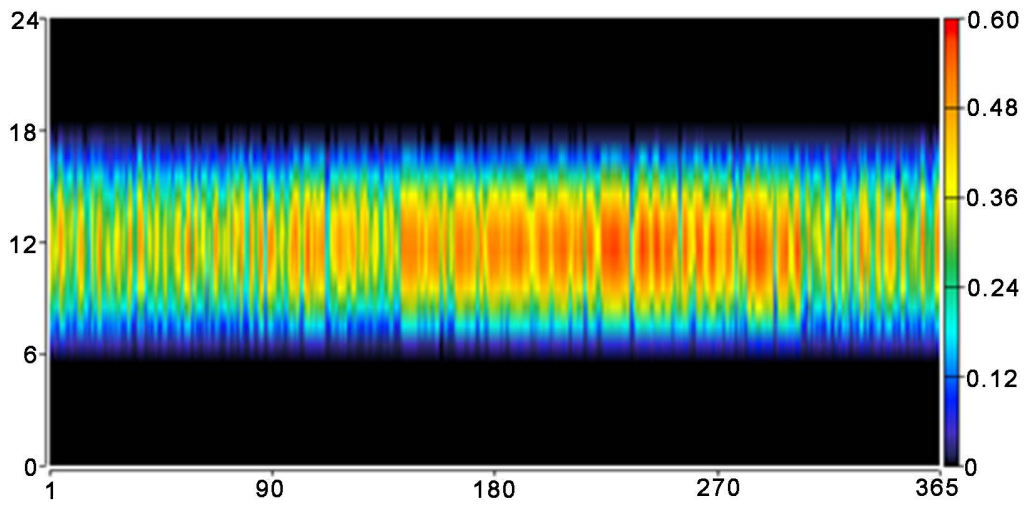

Figure 5. Photovoltaic production for the first year of operation $(\mathrm{kW})$.

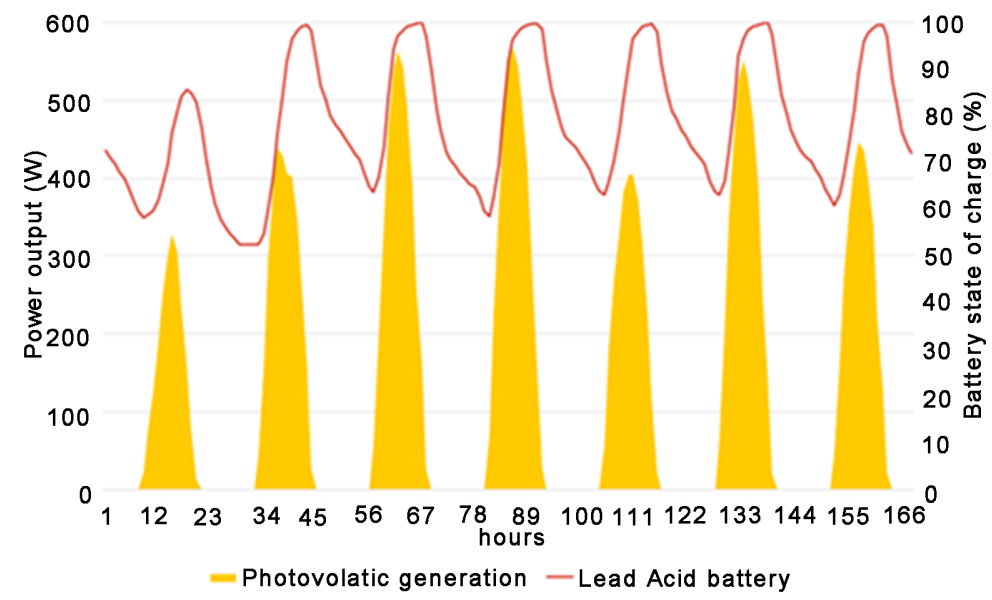

Figure 6. Weekly operation of photovoltaic with bank of battery system.

A financial analysis was made to compare the costs of a pure diesel solution based on the equipment investment cost of US\$ 1300/kVA. We assumed financing with a $1 \%$ interest rate per month during 10 years plus the fuel cost of approximately US\$ 50 per month. Total cost for households reaches US\$ 69 for only $30 \mathrm{kWh} /$ month worth of consumption, a reference gathered during the field trip to Porto Walter. For the least cost alternative, the household bears an investment of US $\$ 5000$ to cover the cost of the solar photovoltaic system and lead acid battery bank (including replacements needed throughout the period). The resulting amortization + operation and maintenance cost amounts to US\$ 72 per month, which is similar to the diesel solution. However, it provides twice as much electricity ( $60 \mathrm{kWh} /$ month), as modeled in HOMER.

The solar system with battery bank is a better solution than the diesel genset system. It provides roughly twice as much electricity for a similar monthly expending. As discussed, this alternative has the potential to positively impact the remote communities, given their current lack of services that require reliable electricity supply.

Even though Brazil already has the Luz para Todos program, oriented to increase socio-economic indexes of poorly served communities by strengthening 
electrification, many remote communities haven't benefited from it, mainly due to political issues. In this sense, an alternative that would allow communities to double their power supply with the same expending is a good candidate for modifying current public policy.

Such policy should target how remote communities would finance the renewable-based alternative. A possibility is to provide credit to households in remote communities for the purchase of a solar system. The federal government would buy standardized, quality-assured solar systems and procure local companies to supply, operate and maintain the systems in exchange for a monthly payment.

The solution enables households to immediately increase their power supply conditions at no additional federal spending. Another positive aspect of this policy is its potential to speed up the objective of universalization of supply of the Luz para Todos program.

An alternative scheme is based on applications for the so-called results-based financing $(\mathrm{RBF})$ to fund mini-grids. The program provides financial incentives for private companies to build and run mini-grids in remote rural areas. Local companies propose grids connected projects. The RBF project tackles the financing gap in mini-grid projects: financing grants make projects financially viable, while ensuring that federal grants of Luz para Todos are disbursed only when results are delivered. In addition, companies will not have to wait for years to recoup their investment cost, because they would receive a large share of the investment cost during the first year of operation. This policy design strengthens a market-based approach and could be complemented by others to minimize the costs of the equipment, such as exemptions of import duties, for instance.

The grant delivery requirements are based on proved record of actual delivery of solutions by the proponent. Loan guarantees may be a challenge for the access by local companies of financing schemes for the development of these solutions. A program for supporting guarantees should be deployed, as it often happens with energy efficiency projects that acquire equipment that needs to be financed by developers.

\section{Conclusions}

Despite the recent effort to improve the efficiency of supplying electricity in isolated systems in Brazil, there are still areas poorly supplied by expensive diesel generators that contribute to greenhouse emissions. Furthermore, remote communities within the isolated systems have little or no access to electricity.

In this study, we evaluated an alternative solution for the energy supply of isolated communities of Porto Walter, a municipality in the State of Acre, in Brazilian Amazon. We propose an alternative solution that provides better services in technical, economic and environmental terms with respect to the current one.

Energy supply alternatives were tested considering hybrid systems that combine diesel gensets, solar PV and battery bank. The HOMER software, developed 
by NREL for the optimization of microgrids, was utilized in this study with input data based on local references.

The systems were dimensioned after data gathered in a visit to Porto Walter and after the SIGFI60 criteria, which provide technical specifications for a solar photovoltaic system that supplies $60 \mathrm{kWh}$ per month. The load curve modeled for a household in a small remote community should be able to support higher energy consumption, allowing the local population to have refrigerators and power availability throughout the day.

The main results showed that the only photovoltaic alternative has a lower LCOE than the hybrid case. The optimum solution also differs from the one recommended to meet the SIGFI60 criteria with less installed capacity for the system components.

A financial analysis compared the costs of an only diesel supply versus a photovoltaic only (with battery bank) system. The results showed that it would be possible for the communities to consume twice as much electricity if the solar + battery system was used for a similar amount of money spent. This conclusion is not modified if logistic costs are added, considering the replacement every four years of the lead acid batteries and their proper disposal.

We suggest a public policy to be implemented by the federal government to promote a market-based solution for remote communities. We conclude that more attention should be given to alternative solutions in the off-grid systems, which historically were entirely based on diesel. With time, benefits will only become more apparent as price drops of solar modules and storage devices-especially those based on lithium-ion batteries with larger efficiencies, lifetime and smaller disposal costs (lead-free) are expected. The solution should be supported by the government due to economic and socio-environmental advantages.

\section{Acknowledgements}

This paper was written as part of an $\mathrm{R} \& \mathrm{D}$ project developed with Brazil Bio Fuels (BBF), an independent power producer that operates in a few mini-grid systems of Brazil.

\section{References}

[1] FGV-EAESP (2016) Cálculo do fator de Emissão de Energia Elétrica para o Sistema Isolado do Amazonas-versão 1.0. [Power Emissions Factor Calculation for the Amazonas Off-Grid System-Version 1.0.] São Paulo.

[2] Eletrobras (2016) Plano anual de custos 2017. [2017 Annual Costs Plan.]

[3] De Freitas, G. and Silveira, S.F.R. (2015) Programa luz para todos: Uma representação da teoria do programa por meio do modelo lógico. [Light for All Program: A Logical Model Representation of the Program's Theory.] Planejamento e Políticas Públicas, 45, 1-22.

[4] Cerqueira, P.G. (2011) Programa luz para Todos-projetos especiais. [Light for All Program-Special Projects.] MME/SEE/DPUE, São Paulo.

[5] Portal Brasil (2015) Programa Luz para Todos é prorrogado até 2018. [Light for All Program Is Extended to 2018.] 
http://www.brasil.gov.br/infraestrutura/2015/01/programa-luz-para-todos-e-prorro gado-ate-2018

[6] Borges, E., Klaus, W., Monteiro, C. and Schwab, T. (2008) Sistemas fotovoltaicos domiciliares-Teste em campo de um modelo sustentável de eletrificaçao rural. [Individual Photovoltaic Systems-Field Testing of a Sustainable Model for Rural Electrification.] II CBEE.

[7] Brasil (2003) Decree n. 4873. Brasília: Presidência da República Casa Civil—Subchefia para Assuntos Jurídicos.

http://www.planalto.gov.br/ccivil_03/decreto/2003/d4873.htm

[8] IBGE (2016) IBGE | Cidades | Acre | Porto Walter | Estimativa da População 2016. [IBGE | Citites | Acre | Porto Walter | 2016 Population Estimation.]

[9] MDA (2011) Plano Territorial de Desenvolvimento Rural Sustentável do Vale do Juruá-Acre. [Territorial Plan of Vale do Juruá's Sustainable Rural Development.]

[10] Eletrobras (2014) Leilão ANEEL 2015_PROJETO DE REFERENCIA-LOTE III. [Energy Auction ANEEL 2015_Reference Project for Third Lot.] Rio Branco.

[11] IBGE (2010) Renda média domiciliar per capita-Brasil. [Average Household Income Percapita-Brazil.] Censo demográfico.

[12] Lambert, T., Gilman, P. and Lilienthal, P. (2006) Micropower System Modeling with Homer.

[13] Homer Energy (2016) HOMER Pro Version 3.7 User Manual. Colorado.

[14] Ramos, M., Vieira, L., Galdino, M.A. and Olivieri, M.M.A. (2015) Avaliação de sistemas fotovoltaicos isolados tipo SIGFI alimentando refrigeradores. [Evaluation of Isolated Photovoltaic Systems like SIGFI for Refrigerators Supply.] XXIII SNPTEE—Seminário Nacional de Produção e Transmissão de Energia Elétrica.

[15] Eletrobras (2015) Especificações Técnicas dos Programas para Atendimento às Regiões Remotas dos Sistemas Isolados no âmbito do Programa Luz para Todos. [Technical Specifications for the Supply of the Isolated Systems' Remote Areas in the Light for All Program.] Ministrio de Minas e En-ergia.

[16] Staffell, I. and Pfenninger, S. (2016) Using Bias-Corrected Reanalysis to Simulate Current and Future Wind Power Output. Energy, 114, 1224-1239. https://doi.org/10.1016/j.energy.2016.08.068

[17] Landau, C.R. (2015) Optimum Tilt of Solar Panels.

\section{Scientific Research Publishing}

Submit or recommend next manuscript to SCIRP and we will provide best service for you:

Accepting pre-submission inquiries through Email, Facebook, LinkedIn, Twitter, etc. A wide selection of journals (inclusive of 9 subjects, more than 200 journals)

Providing 24-hour high-quality service

User-friendly online submission system

Fair and swift peer-review system

Efficient typesetting and proofreading procedure

Display of the result of downloads and visits, as well as the number of cited articles

Maximum dissemination of your research work

Submit your manuscript at: http://papersubmission.scirp.org/

Or contact jpee@scirp.org 